\title{
Reclassification of Promicromonospora pachnodae Cazemier et al. 2004 as Xylanimicrobium pachnodae gen. nov., comb. nov.
}

\author{
Erko Stackebrandt and Peter Schumann
}

Correspondence

Erko Stackebrandt erko@dsmz.de
DSMZ - Deutsche Sammlung von Mikroorganismen und Zellkulturen GmbH, Mascheroder Weg 1b, 38124 Braunschweig, Germany
Owing to the order of descriptions of Cellulosimicrobium variabile (Bakalidou et al., 2002), Xylanimonas cellulosilytica (Rivas et al., 2003), Xylanibacterium ulmi (Rivas et al., 2004), Promicromonospora pachnodae (Cazemier et al., 2003) and two novel authentic species of Promicromonospora (Busse et al., 2003), several of these strains were not or could not be included in studies on the description of most of the other novel species. Only when the 16S rRNA gene sequences of these species became available were the phylogenetic relationships unravelled. As a consequence, Cellulosimicrobium variabile was reclassified as Isoptericola variabilis (Stackebrandt et al., 2004). Fig. 1 displays a 16 S rRNA gene sequence neighbour-joining tree of these organisms and their closest relatives. The similarity values of almost complete sequences of Promicromonosporaceae type strains range between 94.6 and $99 \cdot 2 \%$, with the highest value shared between authentic members of Promicromonospora $(98 \cdot 4-99 \cdot 2 \%)$. P. pachnodae DSM $12657^{\mathrm{T}}$ and Xylanibacterium ulmi XIL08 ${ }^{\mathrm{T}}$ show $98 \%$ sequence similarity, whereas values determined for $P$. pachnodae and the four authentic species of Promicromonospora are slightly lower, ranging between $95 \cdot 5$ and $96 \cdot 1 \%$.

The generic affiliation of $P$. pachnodae was based on the presence of the following characters: phylogenetic position, presence of a fragmenting mycelium, matching $16 \mathrm{~S}$ rRNA gene sequence signatures (Stackebrandt et al., 1997), biochemical properties that fall into the range of those of
Promicromonospora species and the presence of peptidoglycan type A4 $\alpha$ [L-Lys as diamino acid and a dicarboxylic amino acid (Glu or Asp) as interpeptide bridge constituent]. However, the composition of peptidoglycan amino acids in Promicromonospora species needs further discussion. The presence of the Lys-Ala-Glu type was determined in Promicromonospora sukumoe and confirmed in this study for Promicromonospora citrea as originally stated by Evtushenko et al. (1984), using the methods of Schleifer \& Kandler (1972) and Groth et al. (1999). By contrast, Kalakoutskii et al. (1989) reported the type A3 $\alpha$, L-LysAla-Ala, for P. citrea, and Busse et al. (2003) indicated the presence of glycine in the peptidoglycan of Promicromonospora aerolata and Promicromonospora vindobonensis. As actinobacterial genera are usually coherent with respect to peptidoglycan type $A 4 \alpha$, the peptidoglycan composition was redetermined for the two latter species. Indeed, the composition must be corrected to the composition LysAla-Glu as found in the other two recognized Promicromonospora species.

Menaquinone composition and polar lipids were not reported by Cazemier et al. (2003) for P. pachnodae; these compounds were analysed in this study using the methods of Minnikin et al. (1979), Collins \& Jones (1980) and Groth et al. (1999). The chemotaxonomic properties of P. pachnodae and related organisms are shown in Table 1. The menaquinone MK-9 $\left(\mathrm{H}_{4}\right)$ together with phosphatidylglycerol, 


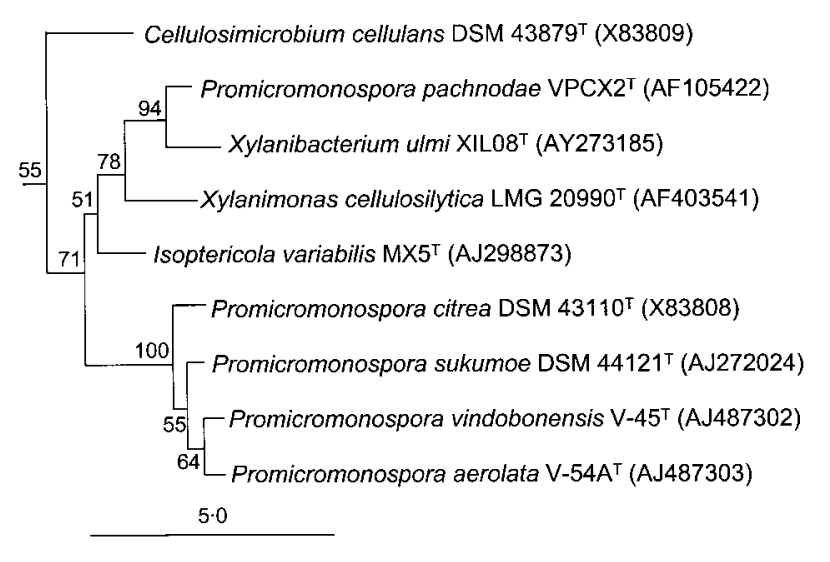

Fig. 1. Phylogenetic relatedness among members of Promicromonospora, Xylanimonas, Xylanibacterium, Isoptericola and Cellulosimicrobium based upon 16S rDNA sequence comparison. Beutenbergia cavernae DSM 12333 ${ }^{\top}$ (Y18378) and Jonesia denitrificans DSM $20603^{\top}$ (X83811) served as a root. The dendrogram was generated by neighbour-joining analysis (Felsenstein, 1993). Numbers within the dendrogram indicate the percentages of occurrence of the branching order in 100 bootstrapped trees (only values of $50 \%$ and above are shown). Bar, 5 nucleotide substitutions per 100 nucleotides. diphosphatidylglycerol, phosphatidylinositol and unknown phospholipids are commonly present in all these organisms, and thus are not discriminatory. This is also the case for the fatty acid pattern (Cazemier et al., 2003).

P. pachnodae shares with Xylanibacterium ulmi and Xylanimonas cellulosilytica the ability to produce xylanases. Comparison of metabolic properties of members of Promicromonosporaceae reveals a significant number of negative reactions for $P$. pachnodae in the API 50CHE substrate panel (Table 2).

The topology of the 16S rDNA dendrogram, recovered by different phylogenetic methods, suggests that $P$. pachnodae is not a member of the recognized genus Promicromonospora. However, as pointed out previously in the literature (Schumann et al., 2001; Stackebrandt et al., 2004), and consistent with a polyphasic approach to classification, branching points, chemotaxonomic, morphological and cultural properties should be used for reclassification purposes. The rationale for the reclassification of $P$. pachnodae as the nucleus of a new genus, adjacent to the genera Xylanimonas and Xylanibacterium, is based upon the presence of the peptidoglycan type L-Lys-L-Ser-D-Glu, which is not found in recognized species of Promicromonosporaceae or in phylogenetically neighbouring species.

Table 1. Morphological and chemotaxonomic characteristics that differentiate strains of the genera Cellulosimicrobium, Xylanimonas, Promicromonospora and related species

Data from Rivas et al. (2004), Busse et al. (2003) and our own data. Abbreviations: Ara, arabinose; Gal, galactose; Rha, rhamnose; Fuc, fucose; Man, mannose; Glc, glucose, Xyl, xylose; PG, phosphatidylglycerol; DPG, diphosphatidylglycerol; PI, phosphatidylinositol; PIM, phosphatidylinositol mannoside; PL, unknown phospholipid; PGL, unknown phosphoglycolipid; GL, unknown glycolipid. -, Negative; W, weak; + , positive.

\begin{tabular}{|c|c|c|c|c|c|}
\hline Property & $\begin{array}{l}\text { P. pachnodae } \\
\text { DSM } 12657^{T}\end{array}$ & $\begin{array}{l}\text { Xylanibacterium } \\
\text { ulmi XIL08 }^{\mathrm{T}}\end{array}$ & $\begin{array}{c}\text { Xylanimonas } \\
\text { cellulosilytica XIL07 }\end{array}$ & $\begin{array}{l}\text { I. variabilis } \\
\text { DSM } 10177^{\mathrm{T}}\end{array}$ & $\begin{array}{c}\text { Authentic } \\
\text { Promicromonospora } \\
\text { species }\end{array}$ \\
\hline Mycelium & Mycelia-like fringes & - & - & Primary mycelium & Mycelium \\
\hline Peptidoglycan composition & L-Lys-L-Ser-D-Glu & L-Lys-L-Ala-D-Glu & L-Lys-D-Asp & L-Lys-D-Asp & L-Lys-L-Ala-D-Glu* \\
\hline Cell-wall sugars & Rha, Gal, Glc & $\begin{array}{c}\text { Rha, Fuc, Man, } \\
\text { Gal, Ara, Glc }\end{array}$ & Gal, Rha & Rha, Gal, Glc & $\begin{array}{l}\text { Rha, Gal, Glc or } \\
\text { Glc, Gal, Xyl }\end{array}$ \\
\hline Phospholipid composition & PG, DPG, PI, 3 PLs & $\begin{array}{c}\text { PG, DPG, } \\
\text { PI, PIM }\end{array}$ & $\begin{array}{l}\text { PG, DPG, } \\
\text { PI, PIM }\end{array}$ & $\begin{array}{l}\text { PG, DPG, } \\
\text { PI, } 2 \text { PLs }\end{array}$ & $\begin{array}{l}\text { PG, DPG, } 2 \text { GLs, } \\
2 \text { or } 3 \text { PGLs, PL } \\
\text { or PG, DPG, PI }\end{array}$ \\
\hline
\end{tabular}

${ }^{\star}$ Conflicting reports on the peptidoglycan type are given in the literature: L-Lys-Ala 2 (Kalakoutskii et al., 1989) and Lys-Ala-Glu (Evtushenko et al., 1984). 
Table 2. Physiological characteristics of closely related members of the family Promicromonosporaceae

Strains: 1, P. citrea DSM $43110^{\mathrm{T}}$; 2, P. sukumoe DSM $44121^{\mathrm{T}} ; 3$, P. vindobonensis $\mathrm{V}^{\mathrm{T}} 5^{\mathrm{T}} ; 4$, P. aerolata V54A $\mathrm{T}^{\mathrm{T}}$; 5 , P. pachnodae DSM $12657^{\mathrm{T}}$; 6, Xylanibacterium ulmi XIL08 ${ }^{\mathrm{T}} ; 7$, Xylanimonas cellulosilytica XIL07 ${ }^{\mathrm{T}}$. The following compounds were used by all strains in API 50 CHE: glycerol, L-arabinose, D-xylose, D-lyxose, galactose, D-fructose, D-mannose, aesculin, cellobiose, sucrose, trehalose, $\beta$-gentiobiose and Dturanose. None of the strains utilized dulcitol, inositol, sorbitol, D-raffinose, inulin or L-arabitol. -, Negative; +, positive; ND, not done.

\begin{tabular}{|c|c|c|c|c|c|c|c|}
\hline Reactions for: & 1 & 2 & 3 & 4 & 5 & 6 & 7 \\
\hline L-Sorbose & - & - & - & + & - & $-{ }^{\star}$ & - \\
\hline D-Arabinose, mannitol, D-arabitol, methyl $\alpha$-D-mannoside, methyl $\beta$-xyloside & + & + & + & + & - & - & - \\
\hline Salicin, glycogen, D-fucose & + & + & + & + & - & - & + \\
\hline Starch & + & + & + & + & - & ND & + \\
\hline L-Xylose & - & - & + & - & - & - & - \\
\hline Rhamnose & + & - & + & + & - & - & + \\
\hline Methyl $\alpha$-D-glucoside, melezitose & + & - & - & - & - & - & - \\
\hline$N$-Acetylglucosamine & - & - & + & + & + & $-{ }^{\star}$ & - \\
\hline Arbutin, L-fucose & - & + & + & + & - & - & + \\
\hline Gluconate, 2-ketogluconate & - & - & + & + & - & $+^{*}$ & - \\
\hline
\end{tabular}

${ }^{\star}$ Reactions for L-sorbose, $\mathrm{N}$-acetylglucosamine and gluconate differ from those given in the species description of Xylanibacterium ulmi (Rivas et al., 2004).

The reclassification is also based on morphological criteria. Similarities in polar lipids, fatty acid composition, isoprenoid composition (Table 1) and base composition of DNA are family-specific rather than genus-specific characters, whereas physiological differences are species-specific (Table 2). The generic name Xylanimicrobium is suggested for the novel combination in order to highlight the phylogenetic similarity of the xylanase-producing type strain DSM $12657^{\mathrm{T}}$ (Cazemier et al., 1999) to members of the genera Xylanimonas and Xylanibacterium.

\section{Description of Xylanimicrobium gen. nov.}

Xylanimicrobium (Xy.la.ni.mi.cro'bi.um. N.L. neut. n. xylan xylan a polysaccharide; Gr. adj. mikros small; Gr. masc. n. bios life; N.L. neut. n. Xylanimicrobium xylan-hydrolysing microbe).

The description is based on the original description of the species Promicromonospora pachnodae DSM $12657^{\mathrm{T}}$ and data from Cazemier et al. (2003) and our own data. Grampositive, non-spore-forming, irregular rod-shaped cells, non-motile, occurring singly or in pairs. Aerial mycelium not formed. The murein contains the amino acids lysine, glutamic acid and serine (D-Lys-L-Ser-D-Glu), belonging to the peptidoglycan type $\mathrm{A} 4 \alpha$, variation A11.48. Nglycolylmuramic acid, mycolic acids and hydroxy fatty acids are absent. Whole cell sugars are rhamnose, galactose and glucose. The main menaquinone is MK9 $\left(\mathrm{H}_{4}\right)$. Major fatty acid is aiC $\mathrm{C}_{15: 0}$. Phospholipids are phosphatidylglycerol, diphosphatidylglycerol, phosphatidylinositol and three unknown phospholipids. Catalase, oxidase and aminopeptidase positive. Xylanolytic; facultative anaerobic, acid is produced from some carbohydrates. DNA G $+\mathrm{C}$ content is $70 \mathrm{~mol} \%$. Phylogenetically related to Xylanimonas cellulosilytica, Xylanibacterium ulmi and I. variabilis.

The type species is Xylanimicrobium pachnodae (Cazemier et al. 2004).

\section{Description of Xylanimicrobium pachnodae (Cazemier et al. 2004) comb. nov.}

Xylanimicrobium pachnodae (pach.no'dae. N.L. gen. n. pachnodae of Pachnoda, referring to the source of the micro-organism, Pachnoda marginata).

Basonym: Promicromonospora pachnodae Cazemier et al. 2004

The description is that of $P$. pachnodae and data included in the publication of Cazemier et al. (2003), supplemented with our own data. In the exponential phase of growth, cells are pleomorphic rods $(0.4-0.6 \times 0.6-3.0 \mu \mathrm{m})$, whereas, in the stationary phase, spherical cells dominate (diameter $0 \cdot 5-0 \cdot 7 \mu \mathrm{m})$. Under aerobic conditions in basal medium with glucose as carbon source, nocardioform mycelia-like 
fringes dominate; these forms are absent under anaerobic conditions. In rich media, cells are more homogeneously distributed. Aerobic to facultatively anaerobic, fermenting glucose, xylose, maltose, lactose (weak) and sucrose; fermentation products of glucose or xylose are formate, lactate, ethanol and acetate but not succinate. Aerobically, cells grow with high densities with beach litter, $\mathrm{NaOH}$ pretreated beach litter, xylan, carboxymethylcellulose, cellobiose, glucose, xylose and brain heart infusion medium. Optimum growth at $\mathrm{pH} 7.5$ and $35^{\circ} \mathrm{C}$. Similar $\mathrm{pH}$ and temperature optima are found under anaerobic conditions. Nitrate reduction is positive, gelatin is hydrolysed. Major fatty acids are $\mathrm{aiC}_{15: 0}(58.7 \mathrm{~mol} \%), \mathrm{iC}_{16: 0}(8.5 \mathrm{~mol} \%)$, $\mathrm{C}_{14: 0}(8 \cdot 0 \mathrm{~mol} \%), \mathrm{iC}_{15: 0}(6 \cdot 8 \mathrm{~mol} \%), \mathrm{C}_{16: 0}(6 \cdot 1 \mathrm{~mol} \%)$ and $\mathrm{C}_{15: 0}(5.5 \mathrm{~mol} \%) . \mathrm{iC}_{14: 0}(3.9 \mathrm{~mol} \%)$ and $\mathrm{aiC}_{17: 0}$ $(1.9 \mathrm{~mol} \%)$ occur in smaller amounts. In addition to the reaction indicated in Table 2, the following reactions are observed in the Biolog GP2 microtitre plate substrate panel (only strong positive reactions that are not already listed in Table 2 are listed): glycogen, mannan, Tween 40, $\mathrm{N}$-acetyl-D-glucosamine, amygdalin, D-lactose, D-glucose, lactulose, D-mannose, methyl $\beta$-D-galactoside, 3-methyl glucose, methyl $\alpha$-D-glucoside, palatinose, D-psicose, D-ribose, D-tagatose, D-trehalose, methyl pyruvate, 2'-deoxyadenosine, inosine, uridine, adenosine $5^{\prime}$ monophosphate, thymidine $5^{\prime}$-monophosphate, fructose 6-phosphate, glucose 1-phosphate and glucose 6-phosphate. Isolated from the intestine of the rose chafer Pachnoda marginata (Scarabaeidae, Coleoptera).

The type strain is $\operatorname{VPCX}^{\mathrm{T}}\left(=\mathrm{DSM} 12657^{\mathrm{T}}=\mathrm{NCCB}\right.$ $\left.100020^{\mathrm{T}}\right)$.

\section{References}

Bakalidou, A., Kämpfer, P., Berchtold, M., Kuhnigk, T., Wenzel, M. \& König, H. (2002). Cellulosimicrobium variabilis sp. nov., a cellulolytic bacterium from the hindgut of the termite Mastotermes darwiniensis. Int J Syst Evol Microbiol 52, 1185-1192.

Busse, H.-J., Zlamala, C., Buczolits, S., Lubitz, W., Kämpfer, P. \& Takeuchi, M. (2003). Promicromonospora vindobonensis sp. nov. and Promicromonospora aerolata sp. nov., isolated from the air in the medieval chapel 'Virgilkapelle' in Vienna. Int J Syst Evol Microbiol 53, 1503-1507.

Cazemier, A. E., Verdoes, J. C., van Ooyen, A. J. J. \& Op den Camp, H. J. M. (1999). Molecular and biochemical characterization of two xylanase-encoding genes from Cellulomonas pachnodae. Appl Environ Microbiol 65, 4099-4107.
Cazemier, A. E., Verdoes, J. C., Reubsaet, F. A. G., Hackstein, J. H. P., van der Drift, C. \& Op den Camp, H. J. M. (2003). Promicromonospora pachnodae sp. nov., a member of the (hemi) cellulolytic hindgut flora of larvae of the scarab beetle Pachnoda marginata. Antonie van Leeuwenhoek 83, 135-148.

Collins, M. D. \& Jones, D. (1980). Lipids in the classification and identification of coryneform bacteria containing peptidoglycans based on 2,4-diaminobutyric acid. J Appl Bacteriol 48, 459-470.

Evtushenko, L. I., Levanova, G. F. \& Agre, N. S. (1984). Nucleotide composition of DNA and amino acid composition of A4 peptidoglycan in Promicromonospora citrea. Microbiology (English translation of Mikrobiologiya) 53, 519-520.

Felsenstein, J. (1993). PHYLIP. Phylogeny inference package, version 3.5.1. Distributed by the author. Department of Genetics, University of Washington, Seattle, USA.

Groth, I., Schumann, P., Martin, K., Schütze, B., Augsten, K., Kramer, I. \& Stackebrandt, E. (1999). Ornithinicoccus hortensis gen. nov., sp. nov., a soil actinomycete which contains L-ornithine. Int J Syst Bacteriol 49, 1717-1724.

Kalakoutskii, L. V., Agre, N. S., Prauser, H. \& Evtushenko, L. I. (1989). Genus Promicromonospora. In Bergey's Manual of Systematic Bacteriology, vol. 4, pp. 2392-2395. Edited by S. T. Williams, M. E. Sharpe \& J. G. Holt. Baltimore: Williams \& Wilkins.

Minnikin, D. E., Collins, M. D. \& Goodfellow, M. (1979). Fatty acid and polar lipid composition in the classification of Cellulomonas, Oerskovia and related taxa. J Appl Bacteriol 47, 87-95.

Rivas, R., Sánchez, M., Trujillo, M. E., Zurdo-Piñeiro, J. L., Mateos, P. F., Martínez-Molina, E. \& Velázquez, E. (2003). Xylanimonas cellulosilytica gen. nov., sp. nov., a xylanolytic bacterium isolated from a decaying tree (Ulmus nigra). Int J Syst Evol Microbiol 53, 99-103.

Rivas, R., Trujillo, M. E., Schumann, P., Kroppenstedt, R. M., Sánchez, M., Mateos, P. F., Mártinez-Molina, E. \& Velázquez, E. (2004). Xylanibacterium ulmi gen. nov., sp. nov., a novel xylanolytic member of the family Promicromonosporaceae. Int J Syst Evol Microbiol 54, 557-561.

Schleifer, K. H. \& Kandler, O. (1972). Peptidoglycan types of bacterial cell walls and their taxonomic implications. Bacteriol Rev 36, 407-477.

Schumann, P., Weiss, N. \& Stackebrandt, E. (2001). Reclassification of Cellulomonas cellulans (Stackebrandt and Keddie 1986) as Cellulosimicrobium cellulans gen. nov., comb. nov. Int J Syst Evol Microbiol 51, 1007-1010.

Stackebrandt, E., Rainey, F. A. \& Ward-Rainey, N. L. (1997). Proposal for a new hierarchic classification system, Actinobacteria classis nov. Int J Syst Bacteriol 47, 479-491.

Stackebrandt, E., Schumann, P. \& Cui, X. L. (2004). Reclassification of Cellulosimicrobium variabile Bakalidou et al. 2002 as Isoptericola variabilis gen. nov., comb. nov. Int $J$ Syst Evol Microbiol 54, 685-688. 